\title{
DIAGNOSTIC VALUE OF TRU-CUT BIOPSY IN DIAGNOSING BREAST LESIONS
}

\author{
Dobromir D. Dimitrov, \\ Martin P. Karamanliev ${ }^{1}$, \\ Tashko S. Deliyski, \\ Anislav V. Gabarski', \\ Petar P. Vatov ${ }^{1}$, \\ Ruzha O. Gencheva ${ }^{1}$, \\ Chavdar M. Ivanov', \\ Savelina L. Popovska ${ }^{2}$, \\ Genoveva B. Valcheva, \\ Vasil D. Nanev, \\ Tsvetomir M. Ivanov, \\ Hyuliya E. Feradova, \\ Ivelina U. Petrova \\ Division of Surgical Oncology, \\ Medical University - Pleven, \\ Bulgaria \\ ${ }^{1}$ Student Study-Research Group of \\ Surgical Oncology, \\ Medical University - Pleven, \\ Bulgaria \\ ${ }^{2}$ Department of General and Clinical \\ Pathology, \\ Medical University - Pleven, \\ Bulgaria
}

\author{
Corresponding Author: \\ Martin P. Karamanliev, \\ 4, Rila Str., \\ Svishtov, 5250 \\ Bulgaria \\ e-mail: martinkaramanliev@gmail.com
}

Received: December 09, 2016

Revision received: December 19, 2016 Accepted: December 20, 2016

\begin{abstract}
Summary
Breast cancer is the most common cancer in women worldwide. The standard for detecting it includes clinical exam, mammography and fine-needle aspiration cytology. Our aim was to establish the role of the tru-cut biopsy in the diagnosis of malignant breast lesions. We provide a two-year retrospective clinical study defining $98.67 \%$ sensitivity, $100 \%$ specificity, $100 \%$ positive predictive value, $80 \%$ negative predictive value and an overall diagnostic accuracy of $98.73 \%$. In $89.1 \%$ of the malignant lesions, the sample was adequate to define the receptor status. Therefore, tru-cut biopsy is an easy, cheap, safe and accurate alternative to fine-needle aspiration cytology in the diagnosis of breast lesions.
\end{abstract}

Key words: tru-cut biopsy, core needle biopsy, breast lesions

\section{Introduction}

According to the Bulgarian national cancer register breast cancer is the most common malignancy in women (incidence 26.5\%) and the most common reason for cancer death as well. The crude incidence rate in 2013 was 107.2 per 100000 women [1].The standard for breast cancer diagnosis includes clinical exam, mammography and fine-needle aspiration cytology (FNAC). Some recent studies have suggested that tru-cut biopsy (TCB) or core-needle biopsy is in some areas superior to FNAC [2-4]. FNAC has not achieved any improvement in the preoperative decision-making by surgeons and oncologists. On the other hand, TCB is a new, developing, modern method based on a histopathological study of tissue specimen and it can provide all the clinical information needed. Our aim was to establish the role of tru-cut (core) needle biopsy in the pre-operative diagnosis of breast lesions.

\section{Materials and Methods}

A retrospective clinical study was undertaken of all patients who had undergone TCB of breast mass followed by operative treatment between January 2014 and December 2015 at the Department of Surgical Oncology in the University Hospital in 
Pleven. A total of 79 tru-cut biopsies followed by surgical treatment were performed on patients with palpable lesions during the study period.

All lesions were palpable and suspected for malignancy. TCB was performed using a Tru-Cut gun with an 18-gauge needle. A $1 \%$ lignocaineinfiltration anesthetic was administered and skin incision was performed. Lesions were manually immobilized and the needle was inserted under ultrasound-guided visual control (Figure 1).

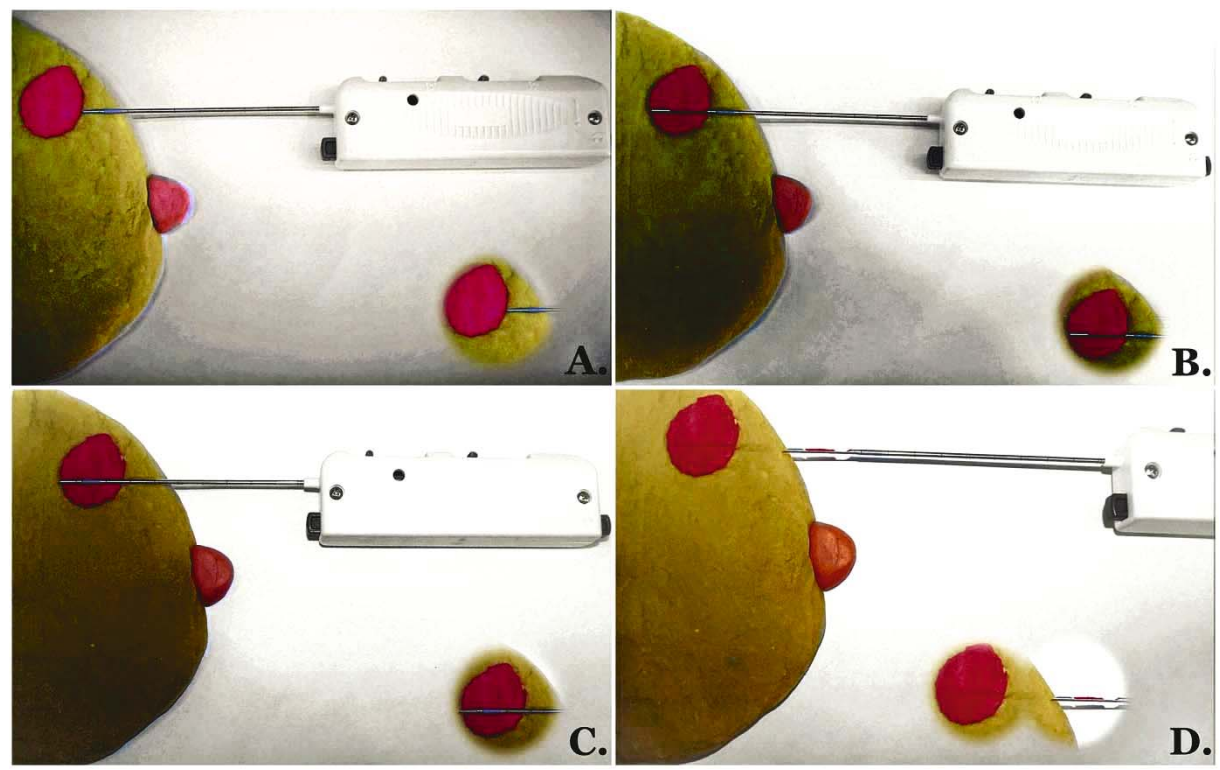

Figure 1. Steps of Tru-cut biopsy technique in suspected lesion-illustrated model: A. Skin incision and needle position next to the tumor mass surface; B. Introduction of the needle inside the tumor mass (manually in semiautomatic needles or automatic-in automatic ones); C. Cutting of the tissue inside the groove using an external sheath of the needle; D. Extracted tumor tissue inside the needle groove outside the breast

Each TCB diagnosis was matched with the post-surgical histopathology result and was labeled as follows: true positive (TP) when positive TCB result for malignancy was obtained and carcinoma in histological study of the postsurgical specimen was found; false positive (FP) when positive TCB result for malignancy obtained and no carcinoma in the histological study of the post-surgical specimen was found; false negative $(\mathrm{FN})$ when negative TCB result for malignancy was not verified in the post-surgical histological study and true negative (TN) when negative TCB result for malignancy was verified in the post-surgical histological study.

The formula used for sensitivity ( $\mathrm{SN}$ ) was $\mathrm{SN}=\mathrm{TP} /(\mathrm{TP}+\mathrm{FN})$. Sensitivity was measured as the proportion of malignancies that were correctly identified as such. The formula used for specificity ( $\mathrm{SP}$ ) was $\mathrm{SP}=\mathrm{TN} /(\mathrm{TN}+\mathrm{FP})$. Specificity was measured as the proportion of benign diseases that were correctly identified as such. The formula used for positive predictive value $(\mathrm{PPV})$ was $\mathrm{PPV}=\mathrm{TP} /(\mathrm{TP}+\mathrm{FP})$. $\mathrm{PPV}$ was measured as the proportion of positive tests for malignancy that were true positive. The formula used for negative predictive value (NPV) was
$\mathrm{NPV}=\mathrm{TN} /(\mathrm{TN}+\mathrm{FN}) . \mathrm{NPV}$ was measured as the proportion of negative malignancy tests that were true negative. The formula used for overall diagnostic accuracy (ODA) was $\mathrm{ODA}=(\mathrm{TP}+\mathrm{TN}) /(\mathrm{FP}+\mathrm{FN}+\mathrm{TP}+\mathrm{TN})$. ODA was measured as the proportion of all results that were true defined.

\section{Results}

The median age of the group was 64 years old (range: 37 to 91 ). All of the patients were women. All TCB included in this study was in different time window followed by surgical treatment including different types of mastectomy and excision biopsy.

Histopathology after tru-cut biopsies showed $74(93.7 \%)$ malignant lesions and 5 benign lesions $(6.3 \%)$. Histopathology of the postsurgical specimen showed 75 (94.9\%) malignant lesions and 4 benign lesions (5.1\%). Comparison of TCB to postsurgical histopathology revealed the following results: 74 true positive cases (93.7\%), zero false positive cases $(0 \%)$, one false negative case $(1.3 \%)$ and 4 true negative cases $(5.1 \%)$, as shown in Table 1 . Therefore, TCB 
showed sensitivity of $98.67 \%, 100 \%$ specificity, $100 \%$ positive predictive value and $80 \%$ negative predictive value. The overall diagnostic accuracy was $98.73 \%$. In $89.1 \%$ of the malignant lesions, the sample was adequate to define the receptor status.

Table 1. Diagnostic value of tru-cut biopsy in our study

\begin{tabular}{lll}
\hline & Malignant disease & Benign disease \\
\hline Positive test for malignancy & $\mathrm{TP}^{*}-74$ cases & $\mathrm{FP} \dagger-0$ cases \\
\hline Negative test for malignancy & $\mathrm{FN}+-1$ case & $\mathrm{TN} \S-4$ cases \\
\hline
\end{tabular}

*TP - true positive; $† F P$ - false positive; $\$ F N$ - false negative; $\S \mathrm{TN}$ - true negative

\section{Discussion}

Multiple studies have been done to determine the usefulness of FNAC and tru-cut biopsy, and separate and compare the two methods. Results vary. Some recent studies have proven that TCB is superior to FNAC $[5,6]$. If compared to TCB, open biopsy showed greater discomfort and pain, higher rate of wound-healing complications, as well as prolonged recovery and higher cost. Open biopsy is also reported to lead to a larger number of operations and higher frequency of positive margins $[7,8]$.

Intraoperative frozen section pathologic analysis of breast mass used for diagnosis is inappropriate method for surgical strategy decisions. It should not be used as a method when making decisions if open biopsy should be extended to mastectomy. Intraoperative frozen section pathologic analysis of sentinel lymph node could be used to find a relatively high percentage of lymph node metastases. This allows the surgeon to perform an immediate (single-stage) axillary lymph node dissection [9-11].

We measured a sensitivity of $98.67 \%, 100 \%$ specificity, $100 \%$ positive predictive value and $80 \%$ negative predictive value. The overall diagnostic accuracy found was $98.73 \%$. There were no false-positive results. There was just one false negative result. One reasons for this could be a sampling error or incorrect size of needles used. Our findings were comparable to those reported in the literature [2-4, 12-15] (Table 2). Most authors have reported results for sensitivity, specificity and PPV that are very close to ours. We believe that the low NPV result that we got was due to the small number of patients with benign disease included in the study.

Table 2. Comparative analysis of clinical results between our and studies found in the literature

\begin{tabular}{llllllll}
\hline Authors & Year & $\begin{array}{l}\text { Number of } \\
\text { patients (n) }\end{array}$ & Sensitivity & Specificity & PPV & NPV & $\begin{array}{l}\text { Diagnostic } \\
\text { Accuracy }\end{array}$ \\
\hline Our results & $\mathbf{2 0 1 6}$ & $\mathbf{7 9}$ & $\mathbf{9 8 . 6 7 \%}$ & $\mathbf{1 0 0 \%}$ & $\mathbf{1 0 0 \%}$ & $\mathbf{8 0 \%}$ & $\mathbf{9 8 . 7 3 \%}$ \\
\hline Lacambra et al. [2] & 2011 & 464 & $96 \%$ & $99 \%$ & $99 \%$ & $94 \%$ & - \\
\hline Ahmed et al. [3] & 2010 & 80 & $94.64 \%$ & $91.3 \%$ & - & - & $94.87 \%$ \\
\hline Brunner et al. [4] & 2009 & 120 & $95 \%$ & $100 \%$ & $100 \%$ & $90 \%$ & - \\
\hline Kulkarni et al. [12] & 2009 & 819 & $97.7 \%$ & $94.2 \%$ & $93.1 \%$ & $98.1 \%$ & $95.5 \%$ \\
\hline Homesh et al. [13] & 2005 & 296 & $92.3 \%$ & $94.8 \%$ & $100 \%$ & $100 \%$ & $93.4 \%$ \\
\hline Bdour et al. [14] & 2009 & 175 & $97 \%$ & $100 \%$ & - & - & - \\
\hline Rikabi and Husain [15] & 2013 & 275 & $95.1 \%$ & $100 \%$ & $100 \%$ & $97.2 \%$ & $98.2 \%$ \\
\hline
\end{tabular}

Recent meta-analysis of the diagnostic accuracy of tru-cut biopsy showed the risk of breast cancer despite benign TCB result is less than $1 \%$ in US and $4-6 \%$ in Europe [16]. Tru-cut biopsy results yield information about receptor status, expression of oncogenes and antioncogenes, thus allowing the administration of exact, modern preoperative chemotherapy. In 
this way, it benefits the multidisciplinary planning and could also help to change the surgical strategy that is safer for the patient.

\section{Conclusions}

Tru-cut biopsy is an easy, cost-effective, safe and accurate alternative to fine-needle aspiration cytology in diagnosing breast lesions with an accuracy as high as of $98.73 \%$. Tru-cut biopsy seems superior to fine needle aspiration cytology in detecting suspicious malignant breast lumps because of the possibility to define the lesion's receptor status. It is also superior to open biopsy in terms of safety, hospital stay, costs, postoperative pain and complications.

\section{Acknowledgements}

This research received no specific grant from any funding agency in the public, commercial, or notfor-profit sectors.

\section{References}

1. Valerianova Z, Dimitrova N, Vuzov M, Atanasov T. Overview of cancer incidence, mortality, prevalence and survival in Bulgaria. In: Valerianova Z, Dimitrova N, Vuzov M, Atanasov, editors. Cancer incidence in Bulgaria, 2013. Sofia: Paradigma; 2015; p. 25-7.

2. Lacambra MD, Lam CC, Mendoza P, Chan SK, Yu AM, Tsang JY, et al. Biopsy sampling of breast lesions: comparison of core needleand vacuum-assisted breast biopsies. Breast Cancer Res Treat. 2012;132(3):917-23.

3. Ahmed ME, Ahmad I, Akhtar S. Ultrasound guided fine needle aspiration cytology versus core biopsy in the preoperative assessment of non-palpable breast lesions. J Ayub Med Coll Abbottabad. 2010;22(2):138-42.

4. Brunner AH, Sagmeister T, Kremer J, Riss P, Brustmann $\mathrm{H}$. The accuracy of frozen section analysis in ultrasound-guided core needle biopsy of breast lesions. BMC Cancer. 2009;9:341.

5. Caruso ML, Gabrieli G, Marzullo G, Pirrelli M, Rizzi E, Sorino F. Core biopsy as alternative to Fine-Needle Aspiration Biopsy in diagnosis of breast tumors. Oncologist. 1998;3(1):45-9.
6. Florentine BD, Cobb CJ, Frankel K, Greaves T, Martin S. Core needle biopsy: a useful adjunct to fine-needle aspiration in select patients with palpable breast cancer. Cancer Pathol. 1997;81:33-9.

7. Linebarger $\mathrm{J}$, Landercasper $\mathrm{J}$, Ellis $\mathrm{R}$, Gundrum J, Marcou K, De Maiffe Br, et al. Core needle biopsy rate for new cancer diagnosis in an interdisciplinary breast center evaluation of quality of care 2007-2008. Ann Surg. 2012;255(1):38-43.

8. James TA, Mace JL, Virnig BA, Geller BM. Preoperative needle biopsy improves the quality of breast cancer surgery. J Am Coll Surg. 2012;215(4):562-8.

9. Van Diest J, Torrenga H, Borgstein J, Pijpers R, Bleichrodt P, Rahusen D, et al. Reliability of intraoperative frozen section and imprint cytological investigation of sentinel lymph nodes in breast cancer. Histopathology. 1999;35:14-8.

10. Weiser MR, Montgomery LL, Susnik B, Tan LK, Borgen PI, Cody HS. Is routine intraoperative frozen-section examination of sentinel lymph nodes in breast cancer worthwhile? Ann Surg Oncol. 2000;7:651-55.

11. Chao C, Wong S, Ackermann D, Simpson D, Carter M, Brown M, et al. Utility of intraoperative frozen section analysis of sentinel lymph nodes in breast cancer. Am J Surg. 2001;182(6):609-15.

12.Kulkarni D, Irvine T, Reyes RJ. The use of core biopsy imprint cytology in the 'one-stop' breast clinic. Eur J Surg Oncol. 2009;35(10):1037-40.

13.Homesh NA, Issa MA, El-Sofiani HA. The diagnostic accuracy of fine needle aspiration cytology versus core needle biopsy for palpable breast lump(s). Saudi Med J. 2005;26(1):42-6.

14.Bdour M, Hourani S, Mefleh W, Shabatat A, Karadsheh S, Nawaiseh O, et al. Comparison between fine needle aspiration cytology and tru-cut biopsy in the diagnosis of breast cancer. J Surg Pak. 2008;13(1):19-21.

15.Hussain S, Rikabi A. Diagnostic usefulness of Tru-Cut biopsy in the diagnosis of breast lesions. Oman Med J. 2013;28(2):125-27.

16. Verkooijen HM, Peeters PH, Buskens E, Koot VC, BorelRinkes IH, Mali WP, et al. Diagnostic accuracy of large-core needle biopsy for nonpalpable breast disease: a metaanalysis. Br J Cancer. 2000;82(5):1017-21. 